\title{
RESENHA
}

\section{CONFIANÇA E MEDO NA CIDADE \\ BAUMAN, ZYGMUNT. CONFIANÇA E MEDO NA CIDADE. RIO DE JANEIRO: ZAHAR, 2009}

\author{
José Dantas Sousa Junior
}

A sociedade contemporânea é marcada por diversos aspectos, dentre eles de um mundo mais industrializado e globalizado. Mas este processo de globalização possui um duplo aspecto, tanto positivo como negativo, em virtude da forma de como o capitalismo se estendeu e se estende por todo o mundo. São nas grandes cidades com os maiores números de habitantes, empresas e de tecnologias mais avançadas que se encontram novas formas de relações sociais e materiais, além de mais oportunidades e escolhas para as pessoas. Mas por outro lado também estão os maiores problemas da nossa época, como o medo, a insegurança e a fragilidade dos indivíduos, como identificado e discutido através desta obra de Zigmunt Bauman. Este sociólogo, um dos mais lidos do nosso tempo, novamente entra em cena com suas reflexões sobre o que define como pós-modernidade e faz uma minuciosa análise da vida cotidiana das pessoas dentro do espaço urbano.

Neste trabalho Bauman, faz uma profunda análise do espaço urbano, lugar onde mais se concentra a vida pública, o consumo, as novas formas de relações sociais e em que também são produzidos novos tipos de medo e insegurança. Neste livro publicado em 2005 e que chegou ao Brasil em 2009 Bauman discute em três capítulos alguns importantes e contundentes aspectos das cidades modernas de um mundo cada vez mais globalizado e modernizado. Sabemos que a globalização não é apenas um fenômeno econômico, ela atinge praticamente todas as esferas das sociedades e é responsável pela transformação do espaço e do tempo, uma mistura complexa de processos, mas que, porém, atuam de maneira contraditória, gerando conflitos e mudanças nas relações e nas posições sociais das pessoas. Partindo desta realidade da pós-modernidade, seguese uma análise minuciosa sobre a cidade e a vida contemporânea.

Logo no primeiro capítulo, o autor fala dos medos existentes na sociedade moderna, que passam a não ser como os de tempos atrás apenas dos fenômenos naturais, e entra em cena o medo da "miséria social". Bauman analisa que no mundo pós-moderno os ricos tendem a se tornar e se tornam mais ricos, enquanto os pobres, mais pobres. Existe um medo do que desta pobreza pode trazer, tanto em termos individuais, como sociais e passa-se a ter um sistema de controle de vigilância quanto ao que pode ser decorrente desta desigualdade social. A cidade é marcada pela insegurança, pelo medo e decorre assim uma busca sem fim por tudo que possa, pelo menos e aparentemente, lhe trazer segurança contra tudo que lhe for "estranho" e perigoso.

A sociedade atual é marcada pela exclusão, pessoas que não conseguem se adaptar às novas demandas do mercado e que são colocadas em um processo temporário de exclusão social até serem excluídas de forma definitiva. Bauman dialogando com Castel descreve a sociedade atual como a mais segura que já existiu, levantando ainda mais a contradição existente com o medo e a insegurança das pessoas. Além disto, veem a supervalorização do indivíduo como característica da sociedade moderna e de forma ambivalente a vulnerabilidade deste mesmo indivíduo, assim como também a sua fragilidade.

Neste mesmo pensamento que no segundo capítulo do livro, denominado Buscar abrigo na caixa de Pandora, que Bauman trata da ficção de segurança

"Doutorando do em Ciências Sociais da UFRN. Mestre em Sociologia pela Universidade Federal da Paraíba. Bacharel em Ciências Sociais pela Universidade federal de Campina Grande e Bacharelado em Administração pela Universidade Estadual da Paraíba. 
e da instabilidade das relações sociais. A promessa de progresso ao invés de trazer mais segurança, ao seu inverso trouxe mais insegurança.

\begin{abstract}
"Hoje se formulam previsões apavorantes e fatalistas, e o progresso representa a ameaça de uma inexorável e inevitável mudança que não promete paz nem repouso, mas crises e tensões contínuas, sem um segundo de trégua, uma espécie de "jogo das cadeiras" no qual um segundo de distração pode levar à derrota irrevogável, à exclusão sem apelo". (BAUMAN 2005, p.52 e 53)
\end{abstract}

Podemos ver isto através do avanço tecnológico, que nos deixa com medo sermos deixados para trás. Podemos ver isso na forma como às vezes temos o medo de não conseguir aquilo que se tornou culturalmente obrigatório, nos tornando assim despossuídos e desclassificados em uma sociedade de consumo. Existe o que Bauman chama de "capital do Medo". Isto é referido a uma parcela do mercado que lucra com o medo das pessoas. Podemos ver um exemplo deste medo em "44 cartas do mundo líquido moderno" onde Bauman cita os alarmes falsos e as notícias dadas referentes às doenças e epidemias, que às vezes não se alastram mais rendem notícias e vendas de medicamentos de forma exacerbada e lucrativa. Também podemos extinguir o "capital do medo" a outros campos, como o da vigilância, onde existem empresas responsáveis por construir verdadeiras fortalezas monitoradas com a função de proteger casas e empresas. Esses projetos de vigilância e essas fortalezas já são definidos por Bauman como a "arquitetura do medo". Quanto esta insegurança Bauman cita Ray Surette, segundo o qual "o mundo tal como aparece na televisão assemelha-se a um rebanho de 'cidadãos-cordeiros' protegidos dos 'delinqüentes-lobos', por 'policiais cães-pastor’” (p. 53).

Bauman analisa que na sociedade moderna existem pessoas tidas como "supérfluas", que não estão empregadas, possuidoras de contas bancárias e cartões de crédito, pessoas vistas como "estranhas" e que passam a fazer parte de uma "classe perigosa" para o mercado e para as elites sociais. Assim, no ultimo capítulo denominado de "Viver com estrangeiros" Bauman analisa o medo das pessoas contra esses estrangeiros e a forma de como fazem para se protegerem destes. Estes estrangeiros que Bauman fala são os imigrantes econômicos que são vistos como "gente supérflua" que na modernidade tiveram que buscar os centros industriais a procura de trabalho e de moradia. Algo marcante desde o início do modo de produção capitalista. Isto pode não ser visto apenas como através de países, mas também de regiões e cidades em lugares como o Brasil, não somente com a imigração como também para a migração. Nem precisamos lembrar o processo de migração do nordeste brasileiro para as regiões sul e sudeste, principalmente para São Paulo a partir da metade do século passado, assim como também dentro do próprio nordeste o processo de migração para as maiores e hoje grandes cidades. Quanto ao modelo das grandes cidades, podemos ver um exemplo dado por Bauman (2005, p. 383 39):

"Teresa Caldeira escreve a propósito de São Paulo (a primeira entre as grandes cidades brasileiras em rápida expansão): "Hoje é uma cidade feita de muros. Barreiras físicas são construídas por todo lado: ao redor das casas, dos condomínios, dos parques, das praças, das escolas, dos escritórios... A nova estética da segurança decide a forma de cada tipo de construção, impondo uma lógica fundada na vigilância e na distância."

Hoje estas cidades são locais de exclusão e de estratificação social numa economia global em que a pobreza pode aparecer em qualquer lugar, assim com qualquer lugar é próprio para o medo e a insegurança. Assim, para Bauman as contradições nas sociedades locais são resultado de contradições globais e não se pode resolver os problemas das cidades sem antes resolver um problema de ordem mundial. Bauman no ultimo capítulo fala da mixofobia, o medo de estranhos e a mixofilia, a vontade exacerbada de conviver com estranhos. Devemos de acordo com o autor, reduzir o primeiro e aumentar o segundo. Bauman analisa todos os problemas da cidade moderna, e sabe que viver de forma pacífica ainda á algo muito longe de ser alcançado, mas define que poderíamos nos acostumar a viver em harmonia uns com os outros, respeitando as diferenças de cada um, como a melhor solução.

\section{Referências:}

BAUMAN, Zygmunt. Confiança e medo na cidade. Rio de Janeiro: Zahar, 2009

Recebido: 31-07-2015

Aceito: 20-08-2015 